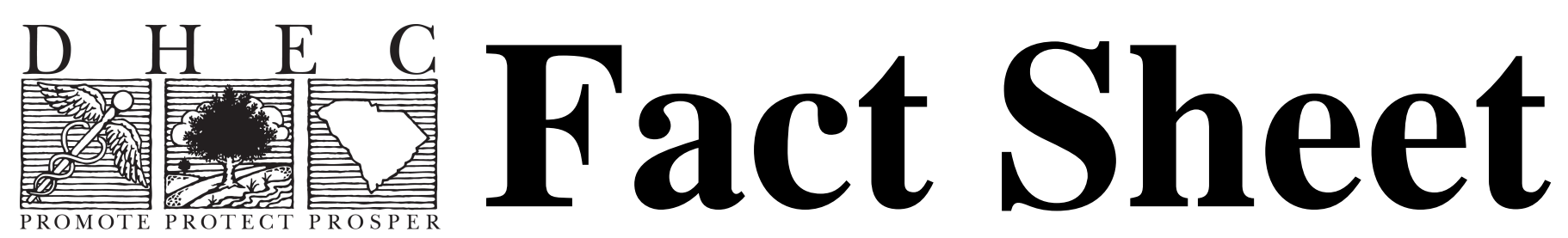

South Carolina Department of Health and Environmental Control • www.scdhec.gov

\title{
National Ambient Air Quality Standards (NAAQS)
}

\section{What are the National Ambient Air Quality Standards (NAAQS)?}

The National Ambient Air Quality Standards (NAAQS) are air quality standards set by the U.S. Environmental Protection Agency (EPA) for six "criteria pollutants" which are among the most harmful to public health and the environment.

Since the amendment of the Clean Air Act (CAA) in 1990, EPA is required to set NAAQS for the criteria pollutants. The law requires EPA to review these standards once every five years to determine if they are appropriate or if new standards are needed to protect public health. In South Carolina, DHEC is the agency responsible for monitoring air quality and reporting to EPA the levels of each of these pollutants in our air.

\section{What are the "criteria pollutants" and where do they come from?}

Ground-level ozone forms in the air when two other types of pollutants, volatile organic compounds (VOCs) and nitrogen oxides, react in the presence of sunlight. The VOCs that form ozone come from vehicle and industrial exhaust as well as evaporated gasoline, solvents, paints and many other sources.

Particulate matter and nitrogen oxides come from diesel cars, trucks and buses, power plants, industries and many other sources.

Carbon monoxide results from the incomplete burning of fuels from cars, buses, trucks, small engines, boilers and some industrial processes.

Sulfur dioxide is generated by coal-fired power plants, industrial sources, residential heating and motor vehicles.

The main sources of lead in humans and other animals are tainted foods and beverages, airborne lead and non-food substances such as paint chips containing lead.

More information on each of the criteria pollutants can be found online at http://www.epa.gov/air/airpollutants.html.

\section{What kinds of NAAQS do we have, and what do they mean?}

The 1990 CAA amendments established two types of standards for each criteria pollutant:

- Primary standards: these protect public health, including the health of "sensitive" populations such as asthmatics, children and the elderly.

- Secondary standards: these protect public welfare and include protection against lower visibility and damage to animals, crops, vegetation and buildings.

\section{What are the standards for each of the criteria pollutants?}

The NAAQS for each of the six criteria pollutants are listed on the next page of this fact sheet. Units of measure for the standards are parts per million (ppm) by volume, milligrams per cubic meter of air $\left(\mathrm{mg} / \mathrm{m}^{3}\right)$, and micrograms per cubic meter of air $\left(\mu \mathrm{g} / \mathrm{m}^{3}\right) .(1 \mathrm{ppm}=1$ drop of water diluted into 50 liters or 1 second of time in roughly 11.5 days.) 


\begin{tabular}{|c|c|c|}
\hline \multicolumn{3}{|c|}{ National Ambient Air Quality Standards } \\
\hline POLLUTANT & STANDARD VALUE & STANDARD TYPE \\
\hline \multicolumn{3}{|l|}{ Carbon Monoxide (CO) } \\
\hline 8-hour Average ${ }^{(1)}$ & $9 \mathrm{ppm}\left(10 \mathrm{mg} / \mathrm{m}^{3}\right)$ & Primary \\
\hline 1-hour Average ${ }^{(1)}$ & $35 \mathrm{ppm}\left(40 \mathrm{mg} / \mathrm{m}^{3}\right)$ & Primary \\
\hline \multicolumn{3}{|l|}{ Lead (Pb) } \\
\hline Rolling 3-Month Average ${ }^{(2)}$ & $0.15 \mu \mathrm{g} / \mathrm{m}^{3}$ & Primary \& Secondary \\
\hline Quarterly Average & $1.5 \mu \mathrm{g} / \mathrm{m}^{3}$ & Primary \& Secondary \\
\hline \multicolumn{3}{|l|}{ Nitrogen Dioxide $\left(\mathrm{NO}_{2}\right)$} \\
\hline Annual Average & $0.053 \mathrm{ppm}\left(100 \mu \mathrm{g} / \mathrm{m}^{3}\right)$ & Primary \& Secondary \\
\hline $1-$ Hour $^{(3)}$ & $100 \mathrm{ppb}$ & Primary \\
\hline \multicolumn{3}{|l|}{ Coarse Particulate $\left(\mathbf{P M}_{10}\right)$} \\
\hline 24-hour Average ${ }^{(4)}$ & $150 \mu \mathrm{g} / \mathrm{m}^{3}$ & Primary \& Secondary \\
\hline \multicolumn{3}{|l|}{ Fine Particulate $\left(\mathbf{P M}_{2.5}\right)$} \\
\hline Annual Average ${ }^{(5)}$ & $15.0 \mu \mathrm{g} / \mathrm{m}^{3}$ & Primary \& Secondary \\
\hline 24-hour Average ${ }^{(6)}$ & $35 \mu \mathrm{g} / \mathrm{m}^{3}$ & Primary \& Secondary \\
\hline \multicolumn{3}{|l|}{ Ozone $\left(\mathrm{O}_{3}\right)$} \\
\hline 8-hour Average (2008 Standard) ${ }^{(7)}$ & $0.075 \mathrm{ppm}$ & Primary \& Secondary \\
\hline 8-hour Average (1997 Standard) ${ }^{(8)}$ & $0.08 \mathrm{ppm}$ & Primary \& Secondary \\
\hline 1-Hour Average ${ }^{(9)}$ & $0.12 \mathrm{ppm}\left(235 \mu \mathrm{g} / \mathrm{m}^{3}\right)$ & Primary \& Secondary \\
\hline \multicolumn{3}{|l|}{ Sulfur Dioxide $\left(\mathrm{SO}_{2}\right)$} \\
\hline Annual Average & $0.03 \mathrm{ppm}$ & Primary \\
\hline 24-hour Average ${ }^{(1)}$ & $0.14 \mathrm{ppm}$ & Primary \\
\hline 3-hour Average & $0.50 \mathrm{ppm}$ & Secondary \\
\hline 1-hour ${ }^{(10)}$ & $75 \mathrm{ppb}$ & Primary \\
\hline
\end{tabular}

(1) This standard cannot be exceeded more than once per year.

(2) Final rule signed October 15, 2008

(3) To attain this standard, the 3-year average of the $98^{\text {th }}$ percentile of the daily maximum 1-hour average at each monitor within an area must not exceed 100 ppb (effective January 22, 2010).

(4) Not to be exceeded more than once per year on average over 3 years.

(5) To attain this standard, the 3-year average of the weighted annual mean $\mathrm{PM}_{2.5}$ concentrations from single or multiple community-oriented monitors must not exceed $15.0 \mu \mathrm{g} / \mathrm{m}^{3}$.

(6) To attain this standard, the 3-year average of the $98^{\text {th }}$ percentile of 24-hour concentrations at each population-oriented monitor within an area must not exceed $35 \mu \mathrm{g} / \mathrm{m}^{3}$ (effective December 17, 2006).

(7) To attain this standard, the 3-year average of the fourth-highest daily maximum 8-hour average ozone concentrations measured at each monitor within an area over each year must not exceed 0.075 ppm (effective May 27, 2008).

(8) (a) To attain this standard, the 3-year average of the fourth-highest daily maximum 8-hour average ozone concentrations measured at each monitor within an area over each year must not exceed $0.08 \mathrm{ppm}$.

(b) The 1997 standard - and the implementation rules for that standard - will remain in place for implementation purposes as EPA undertakes rulemaking to address the transition from the 1997 ozone standard to the 2008 ozone standard.

(c) EPA is in the process of reconsidering these standards (set in March 2008).

(9) (a) EPA revoked the 1-hour ozone standard in all areas, although some areas have continuing obligations under that standard ("anti-backsliding").

(b) The standard is attained when the expected number of days per calendar year with maximum hourly average concentrations above $0.12 \mathrm{ppm}$ is $\leq 1$.

(10) (a) Final rule signed June 2, 2010. To attain this standard, the 3-year average of the $99^{\text {th }}$ percentile of the daily maximum 1-hour average at each monitor within an area must not exceed $75 \mathrm{ppb}$.

DHEC's Bureau of Air Quality, Air Innovations Section provides information on environmental topics. Readers are encouraged to reproduce this material. For more information about air quality issues, please call (803) 8984123 or visit our website at www.scdhec.gov/baq. Please send written correspondence to: DHEC's Bureau of Air Quality, Air Innovations Section, 2600 Bull Street, Columbia, SC 29201.
SPARE THE AIR 